\title{
A MORALIDADE DO DESCARTE E DA SELEÇÃO DE EMBRIÕES
}

\section{Lincoln Thadeu Gouvêa de Frias*}

\begin{abstract}
RESUMO
$\mathrm{O}$ artigo discute as principais questões morais colocadas (1) pelo descarte de embriões necessário para a pesquisa com células-tronco embrionárias e para a fertilização in vitro e (2) pela seleção de embriões usando diagnóstico genético pré-implantação. Depois de apresentar as principais teorias sobre o status moral do embrião, é defendida a tese de que embriões humanos não têm direito à vida, embora devam ser tratados com respeito. Em seguida, a revisão dos quatro principais argumentos contra a seleção de embriões levou à conclusão de que eles não são suficientes para justificar a proibição dessa tecnologia. Por fim, algumas aplicações muito controversas dessa tecnologia são apresentadas e discute-se brevemente qual princípio moral é mais adequado para decidir qual embrião deve ser implantado.
\end{abstract}

Palavras-chave: Embriões. Seleção. Descarte. Genética. Ética.

\begin{abstract}
The paper discusses the major moral questions raised (1) by the discarding of embryos for research with embryonic stem cells and for in vitro fertilization and (2) by the selection of embryos using preimplantation genetic diagnosis. After presenting the main theories about the moral status of the embryo, it is argued that human embryos have no right to life - although they must be treated with respect. Next, the review of the four main arguments against the selection of embryos led to the conclusion that they are not sufficient to justify the prohibition of this technology. Finally, some very controversial applications of this technology are presented and the question of the most appropriate moral principle to determine which embryos should be implanted is briefly discussed.
\end{abstract}

Keywords: Embryos. Selection. Discard. Genetics. Ethics.

\footnotetext{
* Doutorado em Filosofia pela Universidade Federal de Minas Gerais (UFMG). Pesquisador do Núcleo de Estudos do Pensamento Contemporâneo (NEPC-UFMG) e Professor na Universidade José do Rosário Vellano (UNIFENAS).E-mail: lincolnfrias@gmail.com
} 


\section{Introdução}

Há alguma obrigação moral em relação ao embrião humano criado em laboratório e que não foi implantado no útero? Ele merece mais respeito do que o esperma ou o óvulo? Por ser o início de um organismo humano, ele tem o mesmo status moral do que um ser humano adulto?

Nas últimas duas décadas formou-se um intenso debate sobre a situação moral do embrião humano e a ética de seu uso para pesquisa, terapia e reprodução assistida. O principal interesse científico pelos embriões humanos está em suas células-tronco (ou estaminais), capazes de se transformar em qualquer um dos cerca de duzentos tipos de células do corpo humano (pluripotentes) ou, dadas condições propícias, até mesmo em um ser humano completo (totipotentes). A expectativa é que, se os cientistas forem capazes de compreender e controlar esse processo de diferenciação celular, será possível regenerar tecidos danificados ou perdidos por doenças ou acidentes e até mesmo criar órgãos a partir de células do próprio paciente, o que resolveria tanto a rejeição imunológica em transplantados quanto a escassez de órgãos.

Entretanto, para desenvolver essas terapias é necessário manipular os embriões a ponto de torná-los incapazes de se desenvolver. Essa, porém, é apenas uma parte do problema, pois além desse interesse científico, há o interesse reprodutivo pelos embriões.

A seleção genética de seres humanos já acontece lícita e frequentemente, inclusive no Brasil. Ela é feita após a fertilização in vitro, usando o diagnóstico genético pré-implantação (DGPI) para escolher os embriões que serão transferidos para o útero. Atualmente, a seleção de embriões é usada principalmente por casais inférteis (para reduzir a taxa de fracasso decorrente de número anormal de cromossomos) e por casais com alto risco de transmitir doenças genéticas graves. O DGPI adquire ainda mais relevância em países, como o Brasil, em que o diagnóstico pré-natal de fetos seguido de aborto seletivo é proibido. Por ser feito em embriões que não tiveram contato com o útero, pode-se dizer que ainda não há gestação; e como é realizado entre 4 e 6 dias após a fecundação, quando o embrião ainda tem apenas cerca de oito células indiferenciadas, a empatia com o embrião é muito menor do que no caso de fetos. 
Por reduzir significativamente a incidência de doenças hereditárias e anomalias cromossômicas, a seleção de embriões parece ser melhor para todos (pais, filhos e sociedade em geral) e pior para ninguém. Logo, parece ser moralmente irrepreensível e até desejável. Mas isso não é o que acreditam os concepcionistas - aqueles que consideram que o embrião humano tem status moral igual ao de seres humanos adultos pois consideram que a vida humana começa na concepção. Para haver seleção é preciso que o número de embriões criados seja maior do que o que o número que se deseja implantar e que os não escolhidos sejam descartados. Esses embriões excedentes podem ser mortos, criopreservados (congelados) ou usados para pesquisa científica e terapia (derivação de células-tronco). Para quem acredita que o embrião possui status moral completo, todas essas destinações são erros morais tão graves quanto matar seres humanos adultos ou usá-los involuntariamente como fonte de órgãos para transplante. Se o embrião tiver direito à vida, pode-se argumentar que nenhum benefício justificaria sua morte.

Portanto, para justificar a seleção e uso de embriões, é preciso mostrar que embriões humanos não possuem status moral igual ao de seres humanos adultos. A próxima seção resume as principais tentativas teóricas de realizar essa tarefa.

Mesmo que esse objetivo seja alcançado, é preciso resistir às objeções antisselecionistas, aqueles que consideram a seleção de embriões algo intrinsecamente ruim: essa prática é uma reedição da eugenia nazista, está em desacordo com a incondicionalidade do amor paternal, desrespeita os direitos dos portadores de deficiência e pode gerar profunda desigualdade social. Contudo, apesar de serem indicações importantes, essas críticas são equivocadas, como será indicado mais adiante. Por isso, a segunda e a terceira seções tratam da justificava da seleção de embriões e de seus usos mais controversos (escolha segundo suscetibilidades, doenças de expressão tardia, compatibilidade para doação, sexo e características desejáveis).

\section{O status moral do embrião humano}

Ao contrário do que muitos supõem, a questão dos direitos do embrião não é apenas uma versão simplificada da questão dos direitos do 
feto. Duas das justificativas mais razoáveis para a realização de abortos estão ausentes. Os embriões em questão são extracorpóreos, foram fertilizados in vitro, não estão nem nunca estiveram no útero da mulher (boa parte deles inclusive nunca estará) ${ }^{1}$. Portanto, não se aplicam em favor da permissibilidade da morte do embrião o argumento do conflito com os direitos da mulher nem o argumento de que ele seria uma parte do corpo dela. Eles aparecem apenas nas formas mais fracas do direito da mulher de que não implantem o embrião nela e de que aquele embrião surgiu de um tecido seu. Nenhum deles por si só, porém, lhe dá o direito de matar o embrião, caso ele tenha o mesmo status moral que um adulto. Portanto, é preciso investigar qual é a situação moral do embrião.

Se $\mathrm{X}$ possui status moral completo isso significa que ele está em uma situação de igualdade moral com seres humanos adultos, tendo os mesmos direitos morais que eu e você (WARREN, 2000, p. 3-20) - no caso dos embriões é razoável supor que isso se restringe ao direito à vida e à integridade corporal. Há quatro teorias mais frequentes sobre a atribuição de status moral:

- teoria concepcionista: todo homo sapiens tem status moral. A vida humana começa na fecundação (ODERBERG, 2008).

- teoria personalista: todo ser que é pessoa (autoconsciência e racionalidade) tem status moral (WARREN, 2000).

\footnotetext{
1 Os embriões de que trataremos aqui são conhecidos como pré-embriões ou blastocistos. São assim chamados por serem entidades que ainda não passaram pela diferenciação entre as células que formarão a placenta e aquelas que formarão o feto, processo conhecido como gastrulação. Segundo essa definição, o embrião só aparece quando o subconjunto das células do blastocisto que formarão o feto é definido e quando começam a se definir os eixos anterior-posterior e esquerdo-direito que organizarão o desenvolvimento dos tecidos. O feto é um estágio bastante posterior, quando os órgãos já são identificáveis (MAURON, 2004, 707-712). Em maio de 2008, o Supremo Tribunal Federal do Brasil considerou improcedente a Ação Direta de Inconstitucionalidade movida contra a Lei de Biossegurança. Essa Ação defendia que a Lei de Biossegurança era inconstitucional por violar o direito à vida ao permitir que uso científico de embriões excedentes de clínicas de fertilização inviáveis e criopreservados por pelo menos três anos. O julgamento foi cercado de grande debate e cobertura midiática, porém, apesar de ter sido um avanço, a lei brasileira ainda é muito restrita, pois não permite nem que se use embriões viáveis nem que embriões sejam criados especificamente para pesquisa.
} 
- teoria do interesse: todo ser que possui interesses tem status moral (STEINBOCK, 2006; SINGER, 1993; SAGAN \& SINGER, 2007; HARRIS, 2006; MCMAHAN, 2002; BOONIN, 2002).

- teoria do futuro valoroso: todo ser que possui um futuro valoroso possui status moral (MARQUIS, 2007).

A crítica mais frequente à teoria concepcionista é que sua restrição de status moral ao homo sapiens é especista - uma preferência injustificada pela espécie humana. Como mostra a ficção científica, se seres extraterrestres ou animais não humanos demonstrassem autoconsciência e racionalidade, seríamos levados a atribuir-lhes status moral. Portanto, a teoria personalista é mais adequada que a concepcionista.

Entretanto, a teoria personalista é criticada por não explicar por que a autoconsciência e a racionalidade têm valor moral (MARQUIS, 2007, p. 397). A teoria do interesse propõe que essas características têm valor moral por que são indícios suficientes (embora não necessários) de quem possui interesses e apenas quem os possui pode ter direitos, dado que direitos são proteções a interesses (o que é o direito à vida senão a proteção do interesse em continuar vivo?). Portanto, atribuir status moral a X é levar os interesses de $\mathrm{X}$ em consideração (embora seja controverso quando e quais são os interesses que merecem consideração moral (BOONIN, 2002; MCMAHAN, 2002).

Tanto para teoria personalista quanto para a teoria dos interesses, o embrião não tem status moral porque não possui a base fisiológica para possuir consciência - que é o pressuposto para possuir interesses autoconsciência e racionalidade. Somente após a $22^{\mathrm{a}}$ semana de gestação, o córtex cerebral começa a tomar forma (embora a atividade sináptica seja posterior), antes disso o feto é incapaz de consciência.

A teoria do futuro valoroso é uma sofisticação da teoria da potencialidade, segundo a qual embriões têm direito à vida porque são seres humanos em potencial. O principal problema com a teoria da potencialidade é que o fato de que $\mathrm{G}$ seja um $\mathrm{H}$ em potencial não implica que $\mathrm{G}$ tenha os mesmo direitos de $\mathrm{H}$. A teoria do futuro valoroso propõe que a propriedade que confere status moral é o potencial de que os bens da vida seriam experimentados se a vida continuasse: amizade, amor, projetos, identificação com causas maiores e prazeres em geral. Matar um adulto é 
errado nessa perspectiva, não porque ele seja um ser humano, mas porque ele tem um futuro valoroso. Essa propriedade é possuída presentemente (não potencialmente) tanto por adultos quanto por fetos. Logo, matar fetos é errado pelo mesmo motivo que é errado matar adultos (MARQUIS, 2007, p. 198-200).

Porém, isso não vale para embriões humanos porque ainda não possuem individualidade, como demonstra o argumento da gemeação monozigótica (MARQUIS 2007; SINGER 2007; HARRIS 2006; DEVOLDER \& HARRIS, 2007; MCMAHAN 2002, 2007). Até 14 ou 15 dias após a fecundação, é normal que o zigoto se divida em dois ou mais embriões, dando origem a gêmeos. Se o zigoto A se divide em B e $\mathrm{C}$, nem $\mathrm{B}$ nem $\mathrm{C}$ podem ser considerados numericamente idênticos a $\mathrm{A}$, porque, como a identidade numérica pressupõe transitividade, A seria numericamente idêntico a $\mathrm{B}$ e a $\mathrm{C}$, o que implicaria a conclusão de que $\mathrm{B}$ e C são o mesmo indivíduo, o que é falso. Portanto, segundo a teoria do futuro valoroso, não se pode dizer que seja errado matar embriões, pois essa teoria só se aplica a indivíduos, e o embrião não pode ser considerado um indivíduo a menos que a gemeação não seja mais possível - o que acontece após o aparecimento da linha primitiva (o início do sistema nervoso), por volta da segunda semana.

Portanto, apenas segundo a teoria concepcionista o embrião tem status moral. Já mostramos que sua restrição ao homo sapiens é arbitrária. Embora sua afirmação de que a vida humana comece na fecundação seja mais plausível, ela também é inadequada. Há, pelo menos, quatro argumentos contra o concepcionismo:

1) A fecundação é considerada o momento inicial da vida humana porque é então que surge a individualidade genética, mas a suposição de que a individualidade genética determina a individualidade em geral é falsa, pois gêmeos monozigóticos têm o mesmo genoma.

2) $\mathrm{O}$ argumento da gemeação mostra ainda que a teoria concepcionista é inadequada para lidar com os gêmeos monozigóticos. Como vimos, a existência individual de um gêmeo não começa na concepção, mas apenas depois da divisão do zigoto.

3) Durante a reprodução natural, é normal que haja perda embrionária por aborto espontâneo. Para cada embrião gestado, pelo menos 
outros dois foram perdidos (outras estimativas dizem cinco) (ORD, 2008; HARRIS 2006; SAVULESCU, 2002). Se o concepcionismo é verdadeiro, a sociedade tem uma obrigação implacável de abolir ou minimizar essa calamidade, que representa cerca de 200 milhões de mortes por ano. Projetos como as lutas contra as mudanças climáticas, a AIDS ou o câncer devem ser suspensos e um esforço internacional deve ser direcionado a evitar essas mortes, senão toda reprodução passa a ser moralmente condenável (ORD, 2008). Se metodologias morais como o equilíbrio reflexivo ou a tese de que a moralidade só pode exigir o que podemos fazer são levadas em conta, o concepcionismo deve ser repensado, pois essa conclusão é bastante contraintuitiva.

4) O concepcionista defende que apenas organismos humanos tem status moral e que o organismo humano começa na concepção. Entretanto, é difícil sustentar que o embrião seja um organismo, pois suas células são todas iguais, sem integração ou coordenação (MCMAHAN 2007).

Se esses argumentos são robustos, então a teoria concepcionista é falsa. Se ela é falsa, podemos adotar a estratégia o-embrião-não-é-umde-nós. Por não possuírem interesses, embriões não são pessoas. Mas, diferentemente dos fetos, por serem "ambíguos" (DEVOLDER; HARRIS, 2007), embriões não são nem etapas na vida de pessoas. Eles são apenas condições para a existência de pessoas, da mesma maneira que o esperma e o óvulo ${ }^{2}$. Assim como o fato de esperma e óvulo serem condições da

\footnotetext{
2 Logo, conclui-se que "nunca fomos embriões" e que "quando se mata um embrião, não se mata um de nós, apenas se impede que um de nós exista" (MCMAHAN 2007). Não é moralmente factível criticar que se impeça a existência de pessoas possíveis, pois então seria preciso se reproduzir constantemente. É o prejuízo de pessoas potenciais em favor das pessoas atuais. Mas pessoas potenciais não podem ser prejudicadas, pois ser prejudicado é ter sua situação piorada (FEINBERG, 1984). Se as pessoas potenciais não existem, não há como piorar sua situação porque não estão em nenhuma situação, portanto, elas nunca são prejudicadas.

A estratégia o-embrião-não-é-um-de-nós é derivada do artigo de Mcmahan citado acima, mas é em seu livro The Ethics of Killing (2002) que é desenvolvida a teoria de que não somos organismos humanos, mas sim "mentes incorporadas". Ele baseia sua teoria na tese de Parfit (1984, 2007, 2009) de que a identidade pessoal não é o que tem importância moral. As duas teorias são referenciais teóricos primordiais para essa pesquisa.
} 
existência de um ser humano, não justifica a proibição da masturbação e de anticoncepcionais, o fato de embriões serem condições da existência de um ser humano não justifica a proibição da produção de embriões excedentes para fertilização in vitro e seu uso para pesquisa.

Contudo, vários países, que não atribuem status moral aos embriões e permitem a criação de embriões excedentes e seu uso para pesquisa, exigem que se tenha respeito pelos embriões (MANNINEN, 2007). Isso aponta para o fato de que, ainda que o embrião não tenha o mesmo status moral que seres humanos adultos, isso não quer dizer que ele seja um objeto trivial. Segundo Dworkin (1994, p. 101-108), a vida humana tem valor intrínseco: mesmo que a moralidade exija interromper a vida de um feto anencéfalo ou de uma pessoa em estado de coma permanente, a perda da vida em questão é lamentável, porque ela adquire valor por ter recebido investimento natural e afetivo. O mesmo se aplica a cadáveres e restos mortais, e também aos embriões, pois, mesmo que não tenham valor por si e para si, eles de algum modo representam os seres humanos adultos - os quais têm valor incontroverso. Para Steinbock (2006), os embriões têm valor simbólico, o que quer dizer que mesmo que não tenham status moral, eles têm valor moral, por causa desse vínculo conosco, o de serem uma condição da existência de seres como nós.

Na discussão sobre os direitos do feto, está em questão a moralidade do aborto, a morte intencional do feto. Na discussão sobre os direitos do embrião, não é apenas o descarte do embrião, sua morte intencional, que está em discussão, mas sua manipulação, modificação, seu uso como meio para outros fins. Diante desse valor que os embriões têm, ainda que não possuam status moral, o interesse na reprodução é suficiente para justificar o descarte de embriões? O valor das pesquisas com células-tronco é suficiente para justificar usos de embriões que os destruam? Sim, é razoável defender que o interesse na reprodução justifica o descarte de embriões, mesmo porque a reprodução natural também os descarta. Também é razoável supor que os embriões descartados não só possam como devam ser utilizados para pesquisa ao invés de serem simplesmente destruídos (DEVOLDER; SAVULESCU, 2004; PERSSON; SAVULESCU, 2010; SAVULESCU, 2002). 
Mas há questões ainda mais intrincadas que essa análise preliminar não resolve, por exemplo: a restrição da legislação brasileira a usar para pesquisa apenas os embriões excedentes inviáveis é moralmente justificada? Caso seja moralmente aceitável usar embriões excedentes para pesquisa, é também aceitável criar embriões para pesquisa? Se for permitido criar embriões para pesquisa, a transferência de núcleo de célula somática (popularmente conhecida como clonagem terapêutica) e técnicas correlatas para criar embriões devem ser permitidas? Deve também ser permitido criar embriões híbridos (óvulo de animais não-humanos fecundados com esperma humano) para contornar a escassez de óvulos humanos?

\section{A seleção de embriões}

Apesar do grande entusiasmo dos pesquisadores em torno da "engenharia genética" de seres humanos (técnica do DNA recombinante para inserção e silenciamento de genes), a primeira tecnologia a usar a genética molecular para interferir na reprodução humana é o diagnóstico genético pré-implantação $\left(\mathrm{DGPI}^{3}\right)$ para seleção de embriões. Além disso, mesmo quando a modificação do genoma humano for eficiente e segura, a capacidade de teste será sempre muito mais desenvolvida do que a capacidade de intervenção, pois além de ser tecnicamente mais simples, é pressuposta por ela.

Poderia parecer que, se o embrião não tem direito à vida, não há problema moral em selecionar embriões. Para esses antisselecionistas, mesmo que não seja errado matar e usar embriões, é errado selecionar pessoas futuras. Os argumentos mais apresentados em defesa dessa posição são a acusação de eugenia, a ameaça à incondicionalidade do amor paternal, a objeção expressivista em relação aos portadores de deficiência e o receio de que a seleção aumente a desigualdade social.

3 O DGPI consiste em retirar uma célula do embrião fertilizado in vitro para biópsia quando ele tem em torno de oito células, 3 ou 4 dias após a fertilização. O genoma dessa célula é analisado usando duas técnicas: PCR (reação da cadeia de polimerase, usada para análise de genes) e FISH (hibridização fluorescente in situ, usada para análise de cromossomos). Entretanto, essas técnicas permitem verificar apenas uma condição genética por vez. O que torna o processo de seleção bastante lento, caro e demorado. Contudo, há boas perspectivas de que essas limitações técnicas sejam amenizadas. 
A acusação de eugenia (JONAS, 1979; HABERMAS, 2001; FUKUYAMA, 2002) consiste em dizer que selecionar embriões é semelhante às práticas eugenistas, especialmente aquelas feitas pelos nazistas para promover a raça ariana: a esterilização involuntária dos nãoarianos e dos portadores de deficiência, além da inferiorização e extermínio de populações não-arianas. O que há de mais odioso nessas práticas é que elas ignoravam a autonomia dos indivíduos e o princípio da igualdade moral das pessoas. Os procedimentos eram involuntários, centralizados autoritariamente pelo Estado, violentos, excludentes e em prol de um modelo único e imposto de ser humano. Era a submissão do indivíduo ao suposto bem coletivo.

A resposta à acusação eugenista é que a seleção de embriões não implica nenhuma dessas características. Tal como é feita atualmente, ela é completamente voluntária, sem interferência do Estado, não exclui com base em raça ou etnia e não segue nenhum modelo pré-determinado. Ao contrário da eugenia nazista, ela promove os direitos individuais, a liberdade dos pais (de buscar o melhor para seus filhos) e dos filhos (de não receberem uma herança biológica ruim). Mesmo assim, a acusação de eugenia é um lembrete necessário de que a seleção de embriões não deve ser feita de modo involuntário, excludente e autoritário.

O segundo argumento antisselecionista é que a seleção genética é contrária à incondicionalidade do amor paternal (SANDEL, 2007). Segundo essa visão, faz parte da relação entre pais e filhos o fato de que os pais aceitem os filhos independentemente de suas características e isso é algo a ser valorizado, pois é essencial para a dinâmica familiar e social.

Se esse argumento for aceito, os pais não devem nem usar a seleção de embriões para evitar que nasçam crianças com doenças sérias, pois os pais devem amar seus filhos incondicionalmente. Entretanto, esse argumento parece inaceitável, pois é uma prática comum durante a criação dos filhos que os pais usem vários artifícios (escola, remédios, treinamentos etc.) para mudar características dos filhos (agressividade, desatenção, timidez, peso, altura, capacidades cognitivas etc.). Se essas interferências ambientais paternais para moldar os filhos são aceitáveis e compatíveis com o amor paterno, a seleção genética também é, a não ser que se demonstre que aspectos genéticos são moralmente diferentes dos aspectos ambientais. 
É frequente que se aponte como especificidade das características genéticas seu alcance e sua intimidade. Considera-se que no genoma estão determinadas todas as características do indivíduo, aquelas que ele não pode modificar. Alguns vão mais longe e concluem que o genoma é o que define a identidade do indivíduo. Isso implicaria que posteriormente os filhos poderão se enxergar como produtos de seus pais ou mercadorias e assim terão sua autonomia comprometida (HABERMAS, 2001) . $^{4}$

A deficiência desse argumento é pressupor que as intervenções genéticas são determinantes, o chamado "determinismo genético": a crença de que genes (genótipos) causam necessariamente características (fenótipos). Mas isso é cientificamente falso. O genótipo apenas delimita um espectro de fenótipos possíveis. Fatores ambientais é que determinarão qual fenótipo resultará. Podemos diferenciar três tipos de determinismo genético (RESNIK \& VORHAUS, 2006): (a) forte: o gene G quase sempre implica o desenvolvimento da característica C (95\% ou mais); (b) moderado: na maior parte das vezes $\mathrm{G}$ implica $\mathrm{C}$ (acima de 50\%); (c) fraco: $\mathrm{G}$ algumas vezes leva ao desenvolvimento de $\mathrm{C}$ (embora $\mathrm{G}$ aumente a probabilidade de $\mathrm{C}$, ela é menor do que $50 \%$ ) - nesse caso, G está associado a $\mathrm{C}$, mas não é determinante.

A genética molecular cada vez mais apresenta um cenário em que prevalece o determinismo fraco e, em menor medida, o moderado. $\mathrm{Na}$ maioria das vezes, determinados genes são razões necessárias, mas não suficientes, para determinado fenótipo, pois na passagem do genótipo ao fenótipo há dois fatores com forte taxa de interferência: a epigenia (a passagem bioquímica da informação genética a estruturas celulares) e o ambiente. No desenvolvimento celular, vários fatores interferem na expressão de um gene específico, desde a relação com outros genes até erros de funcionamento - p. ex., há características multigênicas, que dependem da combinação de vários (até milhares) de genes para se

\footnotetext{
4 Em geral, quem utiliza esse argumento propõe que haverá restrição da liberdade (1) na medida em que o futuro adulto será incapaz de fazer escolhas livres, pois já estaria determinado pelos genes, (2) na medida em que a intervenção genética limita os comportamentos e planos de vida do paciente e (3) na medida em que aumentam as expectativas e pressões dos pais - além de (4) retirar do agente o mérito de suas conquistas e, especificamente na clonagem, (5) a individualidade do paciente ameaçada.
} 
expressar. $\mathrm{O}$ ambiente tem papel ativo nesse processo, incluindo desde as necessidades nutricionais até exercícios físicos e mentais para desenvolver tendências genéticas. $\mathrm{O}$ que permite concluir que o genoma fornece apenas maiores ou menores possibilidades de desenvolvimento de características, não certezas. Deve-se, portanto, raciocinar a partir de relações causais probabilísticas. No melhor cenário, pais poderão disponibilizar aos filhos um genoma propenso à inteligência supranormal, ao desenvolvimento muscular avantajado ou de dotes musicais excepcionais etc., contudo, a expressão de tais características dependerá do exercício por parte do próprio indivíduo.

Há, porém, algumas características com determinismo forte, por exemplo, a cor dos olhos e o sexo. Logo, pode ser que existam outras, e assim ameacem a liberdade da futura pessoa. Uma resposta interessante propõe que na seleção os pais devem escolher - ou a legislação deve permitir que os pais escolham apenas - as características que impeçam os piores planos de vida, não que determinem o melhor. É “o máximo constrangimento na escolha do plano de vida": o melhoramento deve ser feito sob um véu de ignorância rawlsiano. A escolha sobre quais características escolher deve ser feita ignorando planos de vida específicos, almejando apenas a qualidade de vida em geral (AGAR, 1999, p. 179). Deste modo, a liberdade do futuro indivíduo é potencializada, pois ele não estará sujeito, por exemplo, a defeitos genéticos que limitem sua capacidade motora, imunológica e cognitiva. Se pudermos ter vidas mais saudáveis, mais imunidade e longevidade, seremos mais autônomos e mais livres. Portanto, a objeção do amor incondicional falha por dois motivos: porque a seleção, assim como intervenções ambientais, é compatível com o amor paternal e porque pressupõe o determinismo genético, que é equivocado.

A terceira objeção antisselecionista é o argumento expressivista: ao selecionar embriões para evitar que eles nasçam com deficiências, a seleção genética estigmatiza os portadores de deficiência já existentes (ASCH, 2003; GLOVER, 2006). Especialmente nas duas últimas décadas, por meio de muita mobilização social feita pelos defensores dos direitos dos portadores de deficiência, tanto os formuladores de políticas públicas quanto os pesquisadores começaram a perceber que os portadores de deficiência sofrem injustiças sociais inaceitáveis, pois grande parte do 
que se considera deficiência é construído socialmente. P. ex., se houver estrutura física adequada a cadeirantes em prédios e vias públicas, suas limitações motoras são drasticamente reduzidas. Além disso, a percepção pública de que a vida dos portadores de deficiência é insuportável, inútil e indigna, não é compartilhada pelos próprios portadores de deficiência, que na maioria das vezes desfrutam de qualidade de vida e produtividade equivalentes às dos que não tem deficiências. O que os defensores dos direitos dos portadores de deficiência buscam é que eles sejam tratados com igualdade de respeito. Se os portadores de deficiência já sofrem tanta discriminação e incompreensão, é de se esperar que eles sofrerão ainda mais se forem disponibilizados métodos para evitar que nasçam pessoas com deficiências iguais às deles. Esse argumento defende que, mesmo que a seleção de embriões não seja involuntária e autoritária, ela se assemelha à eugenia nazista ao ser excludente, pois marginaliza os portadores de deficiência.

Essa objeção é essencial por apontar para uma série de injustiças sociais solucionáveis que só há poucos anos começa a ser percebida. Entretanto, ela não é suficiente para proibir a seleção de embriões, pois essa ideia tem consequências inaceitáveis e porque selecionar embriões é compatível com uma moralidade de inclusão de portadores de deficiência (BUCHANAN et al., 2000, p. 258-265).

Selecionar embriões é uma maneira de prevenir deficiências, se isso ofende os portadores de deficiência, qualquer maneira de prevenir deficiências também ofende, seja evitar acidentes, fazer exames ou tomar medicamentos (STEINBOCK, 2002). Embora a maioria dos portadores de deficiência tenha vidas dignas e cheias de realizações, a deficiência continua sendo indesejável por limitar oportunidades e temos fortes motivos para tentar preveni-las. Além disso, mesmo que muitas deficiências sejam agravadas por arranjos sociais, na maioria delas há limitações biológicas que não são eliminadas por mudanças ambientais (SAVULESCU; KAHANE, 2009).

As deficiências nunca serão eliminadas pela seleção genética, pois a maior parte delas é adquirida durante a vida. A existência de pessoas com funcionamento biológico abaixo da média é um fato permanente da vida em sociedade. Portanto, o apoio social aos portadores de deficiência 
deverá sempre ser objeto da justiça social. Por fim, o fato de muitos portadores de deficiência incentivarem as pesquisas para cura e prevenção de suas deficiências mostra que a seleção de embriões é compatível com a moralidade de inclusão.

O quarto argumento contra a seleção de embriões é que ela pode aumentar a desigualdade social ao criar uma sociedade dividida entre aqueles tem melhor patrimônio genético e aqueles que não a tem (um cenário retratado pelo livro Admirável Mundo Novo e pelo filme Gattaca). Há duas afirmações nessa preocupação: (1) que é injusto que apenas algumas pessoas tenham acesso a essas tecnologias e (2) essas tecnologias aumentarão a desigualdade social se apenas os ricos tiverem acesso a elas.

Esse argumento também repousa na suposição de que há algo de especial em relação à genética, pois não é considerado evidentemente imoral que apenas algumas pessoas tenham acesso a determinados bens (p. ex., férias na Europa), inclusive bens que aumentem a desigualdade social (p. ex., ensino médio com professores pós-graduados). Contudo, é plausível supor que a saúde é um bem com significação moral especial por restringir muitas oportunidades - e, no caso de doenças genéticas, serem transmitidas aos filhos. Segundo Buchanan et al. (2000, p. 61-82), ela é um "bem social primário" rawlsiano, portanto, diferenças de acesso à saúde são injustas. Portanto, deve haver um sistema de saúde público universal, e tratamentos de alta complexidade devem ser fornecidos com fundos públicos aos pacientes que não podem pagar.

Qual o modo de distribuição do acesso à seleção de embriões é mais justo? A literatura sobre justiça social oferece três respostas principais: (a) o princípio da igualdade, baseado no igualitarismo puro (pure egalitarianism), que visa fornecer a todos as mesmas oportunidades; (b) o princípio do mínimo decente (decent minimum), baseado no suficientismo (sufficitarianism), que pretende conceder a todos apenas o considerado necessário para uma vida digna e (c) o princípio da diferença, baseado no prioritarismo (prioritarianism), que propõe que a ajuda aos mais necessitados é mais importante do que a ajuda aos que estão em melhor situação. Eles se diferenciam segundo o que consideram mais relevante: para o igualitarismo, a igualdade tem valor por si mesma; para o suficientismo, o que é moralmente importante é que todos tenham o suficiente e para 
o prioritarismo, o que é moralmente importante é beneficiar as pessoas que estão em pior situação. Seguindo as indicações de PARFIT (1996), de que a igualdade não tem valor por si mesma, embora grande desigualdade tenha muito valor negativo, não há motivos para defender o igualitarismo e há motivos para preterir o suficientismo (que aceita muita desigualdade). Portanto, o prioritarismo é a melhor opção - e basta para evitar o acesso desigual e o aumento da desigualdade.

Portanto, nenhum dos quatro argumentos é suficiente para mostrar que seleção é moralmente condenável. Pelo contrário, há indícios de que a seleção de embriões é moralmente elogiável, visto que tenta aumentar o bemestar das pessoas futuras e sua capacidade de realizar seus planos de vida.

\section{Estendendo a seleção a motivos não-terapêuticos}

A reprodução assistida (inseminação artificial ou fertilização in vitro) normalmente só é permitida em casos de infertilidade e de risco de transmissão de doenças genéticas graves. A pretensão dos legisladores é impedir o uso indiscriminado da reprodução artificial, pois ela pode prejudicar o filho (em seus direitos de filiação, se houver doação de gametas) e por razões paternalistas (pois ela pode trazer custos de saúde, psicológicos e financeiros imprevistos, especialmente porque as chances de sucesso não chegam a $40 \%$ ).

A maioria dos países que permitem a seleção de embriões (DGPI) durante a reprodução assistida com fertilização in vitro, a permite apenas por motivos terapêuticos. A principal razão para essa restrição é que a seleção de embriões tem custos morais, pois os embriões têm valor simbólico, ainda que não possuam status moral. Portanto, é preciso que exista um benefício grande para justificar esse custo. Considera-se que apenas a prevenção de doenças é um benefício de magnitude suficiente. Para definir o que é uma condição que mereça ser prevenida, a $\mathrm{HFEA}^{5}$ considera três fatores, um dos quais deve estar presente (no que é seguida por outras instituições):

5 Human Fertility and Embriology Authority (www.hfea.gov.uk), agência reguladora britânica, a entidade mais respeitada em políticas públicas sobre embriologia e fertilidade, principalmente por usar mecanismos de decisão transparentes e deliberativos. 
(1) penetrância completa - o indivíduo necessariamente desenvolverá a condição; (2) que sejam incuráveis - não há tratamento satisfatório disponível e (3) expressão precoce - o indivíduo sofrerá a doença desde os primeiros anos de vida.

Contudo, nos últimos anos, vários países flexibilizaram esses critérios. Começaram a ser aceitos testes para penetrância incompleta ou suscetibilidades (p. ex., dos genes BRCA1 e BRCA2 que predispõem ao câncer de mama) e de doenças de expressão tardia (p. ex., coreia de Huntington e mal de Alzheimer, doenças neurológicas degenerativas cuja incidência só se dá após os 30 ou 40 anos). Embora possam ser classificados como terapêuticos, esses casos são significativamente diferentes da situação padrão: um indivíduo suscetível pode ter uma vida completamente saudável, pois tem apenas uma probabilidade de desenvolver a doença, e um indivíduo que carregue um gene de doença de expressão tardia terá, pelo menos, cerca de metade da expectativa de vida média, só depois disso haverá expressão da doença, por isso há grande controvérsia sobre os testes para essas condições.

Outra situação que não se encaixa na restrição terapêutica padrão é quando o casal já possui um filho nascido, mas que precisa de célulastronco hematopoiéticas para sobreviver, e então decide engravidar usando DGPI para selecionar um embrião que tenha compatibilidade para doação ao irmão. Embora a razão ainda seja terapêutica (curar uma doença), o foco da terapia não é o embrião selecionado, mas uma criança já nascida. Essa situação é controversa, pois se considera que o embrião selecionado não é tratado como "um fim em si", "como tendo valor por si próprio, porque tem fins próprios", "mas simplesmente como um meio". Entretanto, não é claro qual é o prejuízo que é feito a ele. Se ele for amado como os outros segundos filhos, ou mesmo como os filhos concebidos acidentalmente o são, não há problema moral em ele ter sido útil. Inclusive, é mais plausível pensar que ele será mais amado por ter salvado seu irmão.

Outra situação controversa é a seleção de gênero (ou sexo) ${ }^{6}$. Nos países que incorporam a restrição terapêutica, ela só é aceita para prevenir

\footnotetext{
${ }^{6}$ Essa seleção não precisa ser feita por DGPI, pode ser feita antes da concepção por meio da seleção de espermatozóides, pois são eles que definem se o zigoto será XX (feminino) ou XY (masculino), uma vez que o óvulo é sempre X.
} 
doenças ligadas ao sexo. O intuito da restrição é evitar reforçar o viés contra o sexo feminino. Ainda que essa preocupação seja válida, há o caso do balanço familiar: muitas famílias já possuem filho(s) de um dos gêneros e tem um forte desejo de passar pelas experiências de criar filhos do outro gênero e desse modo enriquecer o ambiente familiar. Se essa família já contribuiu para o balanço sexual demográfico, a proibição da seleção de sexo por motivos não-terapêuticos é injustificada. Todavia, a diversidade cultural faz com que as questões sobre o tema da seleção de gênero variem por causa dos diferentes papéis sociais associados ao gênero.

Além dessas controvérsias atuais, há casos mais especulativos. Existe a possibilidade de que traços desejáveis tais como cor dos olhos ou cabelo, altura, inteligência, musicalidade etc. sigam comportamentos hereditários mendelianos (penetrância completa) e sejam detectáveis por análise mutacional tal como se faz atualmente com algumas doenças. Há também a possibilidade de que seja possível criar um número exorbitante de óvulos e de embriões viáveis e ainda a de que a capacidade DGPI se desenvolva a ponto de ser possível analisar todas as características (inclusive multigênicas) de vários embriões em um tempo adequado para que a implantação seja bem sucedida ${ }^{7}$. Se essas possibilidades se efetivarem, haverá um cenário em que a responsabilidade dos pais durante a seleção será ainda maior. Qual deve ser o critério moral para seleção usado pelos pais nessa situação?

Há três opções principais:

- princípio da autonomia reprodutiva: qualquer escolha procreativa feita pelo casal é moralmente permitida na medida em que tenha sido feita autonomamente.

- princípio reprodutivo do nível mínimo: eles têm uma razão moral significativa para escolher algum dos embriões dos quais seja

\footnotetext{
7 Um número infinito de óvulos de uma mesma mulher poderia ser artificialmente criado usando SCNT (transferência de núcleo de célula única, popularmente conhecida como "clonagem terapêutica"). Em outubro de 2008, foi anunciada uma nova técnica de inspeção do embrião chamada karyomapping, que é capaz de analisar vários genes ao mesmo tempo, cujo custo previsto é de U\$1.500. Essa técnica e outras serão muito potencializadas por uma tecnologia em desenvolvimento conhecida como microarrays (ou chips genéticos), cujo propósito é correlacionar vários genes ao mesmo tempo.
} 
possível esperar que venha a ter uma vida digna de ser vivida em detrimento daqueles que não seja possível (BUCHANAN et al., 2000, p. 249).

- princípio da beneficência reprodutiva: eles têm uma razão moral significativa para escolher o embrião cuja vida pode-se esperar que venha ser melhor (terá mais bem-estar) (SAVULESCU; KAHANE, 2009).

O princípio da autonomia reprodutiva aceita casos como o de um casal de surdos que escolhe ter um filho surdo, porque considera que só assim ele poderá vivenciar a cultura dos surdos, que os pais consideram especialmente valorosa ${ }^{8}$. É difícil argumentar que essa escolha é errada, não apenas porque ela envolve a delicada questão dos portadores de deficiência, mas também porque é um exemplo do Problema da Não-Identidade (PARFIT, 1976, 1984): o filho que nasceu surdo não foi prejudicado, porque a única maneira dele existir era com a surdez. Portanto, segundo um princípio pessoal (person-affecting) não há erro moral na escolha dos pais. Para defender que houve erro moral, é preciso que se aplique um princípio impessoal (non-person-affecting) que mostre que os pais erraram porque eles deixaram de aumentar o bem-estar da humanidade, isto é, eles poderiam ter criado um filho que tinha uma maior expectativa de bem-estar (supondo que não surdos tenham uma expectativa maior do que surdos). Entretanto, é preciso definir qual o âmbito de ação de princípios pessoais e de princípios impessoais. É plausível supor que, em se tratando de pessoas futuras, é mais plausível utilizar os impessoais (BOONIN, 2008).

A deficiência do princípio reprodutivo do nível mínimo é ser injustificadamente pouco exigente: se os pais podem escolher um embrião com expectativa melhor, eles são moralmente criticáveis se escolherem outro embrião sem apresentar alguma razão. Portanto, o princípio da beneficência reprodutiva é a melhor opção. Mas isso não significa que deva ser ilegal implantar embriões que não sejam os melhores. Que existam razões morais para os pais escolherem o melhor filho é compatível com

8 O caso mais conhecido é de um casal de lésbicas surdas que selecionaram um doador de esperma que inevitavelmente geraria um filho surdo (CHADWICK; LEVITT, 2006). Embora não tenham usado DGPI, elas poderiam ter usado. Há relatos de situação semelhante em relação a pais com acondronoplasia (nanismo). 
que eles tenham o direito legal à autonomia de escolher um embrião com menor expectativa de bem-estar (que seja surdo ou anão, por exemplo) (SAVULESCU; KAHANE, 2009). Todavia, há motivos para haver uma restrição do nível mínimo com força legal: os pais não podem escolher um embrião cuja vida não será digna de ser vivida (curta, com dor e sofrimento constantes e sem possibilidade de cura). Por beneficência, temos o dever de prevenir dor e sofrimento evitáveis nas pessoas que criamos. Por justiça, temos o dever de não criar pessoas com deficiências físicas e cognitivas que limitarão suas oportunidades de atingir um mínimo decente de tempo de vida com bem-estar. Escolher um embrião que teria vida indigna deve ser ilegal, mas escolher um embrião que não seja aquele com melhores expectativas (por exemplo, um surdo) deve ser lícito embora não recomendável? Durante a pesquisa, essa intrincada questão será aprofundada por meio das ideias de vida indigna e de prejuízo impessoal.

Além do respeito à autonomia e à diversidade de valores, a implementação legal tanto do princípio da beneficência quanto da restrição do nível mínimo são dispensáveis por causa do duplo alinhamento de interesses: os interesses reprodutivos dos pais normalmente estão alinhados aos dos filhos e os interesses do Estado normalmente estão alinhados aos interesses dos filhos e dos pais (BUCHANAN et al., 2000, p. 324). O desalinhamento e conflito entre esses interesses é a exceção. O padrão é que os pais defendam os interesses dos filhos e o Estado defenda os interesses dos cidadãos, ao menos em sociedades democráticas como a nossa.

\section{Conclusão}

A análise precedente procurou mostrar que, embora tenhamos razões para não usarmos os embriões trivialmente e embora a seleção de embriões seja um procedimento moralmente delicado, os benefícios são grandes e, em princípio, nenhuma pessoa é prejudicada. O passado nazista e a defesa dos direitos dos portadores de deficiência são questões que devem sempre estar presentes para impedir erros morais, mas não são motivos para proibir a pesquisa e a seleção de embriões. Há e haverá usos incontroversos e controversos dos embriões e do DGPI (e métodos futuros de seleção de embriões). A ética deve contribuir para o debate público sobre 
quais deles devem ser incentivados, quais permitidos e quais proibidos, levando em consideração se a importância dos interesses reprodutivos ou científicos é suficiente para justificar a criação e descarte dos embriões e se a seleção prejudicará a pessoa futura, estigmatizará pessoas existentes ou criará outros prejuízos sociais.

\section{Referências}

AGAR, Nicholas. Liberal Eugenics In: SINGER, Peter; KUHSE, Helga (Org.). A Companion to Bioethics. Oxford: Blackwell, 1999

BOONIN, David. A Defense of Abortion. Cambridge: Cambridge University Press, 2002.

. How to Solve the Non-Identity Problem. Public Affairs Quarterly, Champaign, v. 22, n. 2, p. 127-57, Abril. 2008.

BUCHANAN, Allen; BROCK, Dan W. DANIELS, Norman; WIKLER, Daniel. From Chance to Choice: Genetics and Justice. Cambridge: Cambridge University Press, 2000.

CHADWICK, Ruth; LEVITT, Mairi. Genetic Technology: A Threat to Deafness In: KUHSE, Helga; SINGER, Peter (Ed.). Bioethics - An Anthology. 2 ed. Oxford: Blackwell, 2006.

DAVIS, Alison. Right to Life of Handicapped In: KUHSE, Helga; SINGER, Peter (Ed.). Bioethics - An Anthology. 2 ed. Oxford: Blackwell, 2006.

DEVOLDER, Katrien; HARRIS, John. The ambiguity of the Embryo: ethical inconsistency in the human embryonic stem cell debate. Metaphilosophy, New Haven, v. 38, n. 2-3, p. 153-169, Abr. 2007.

; SAVULESCU, Julian. The Moral Imperative to Conduct

Embryonic Stem Cell and Cloning Research. Cambridge Quaterly of Healthcare Ethics, v. 15, p. 7-21, 2006.

DWORKIN, Ronald. O Domínio da Vida-Aborto, Eutanásia e Liberdades Individuais. Tradução de Jefferson. Luiz Camargo. São Paulo: Martins Fontes, 2003.

FRANCIS, Leslie. Pickering Disability In: FREY, Richard G.; WELLMAN, Christopher H. (Ed.). A Companion to Applied Ethics. Oxford: Blackwell, 2003. 
FUKUYAMA, Francis. Our Posthuman Future: Consequences of the Biotechnology Revolution. New York: Farrar, Straus, and Giroux, 2002. GLOVER, Jonathan. Choosing Children - genes, disability and design. Oxford: Clarendon Press, 2006.

HABERMAS, Jürgen (2001). O Futuro da Natureza Humana: a caminho de uma eugenia liberal? Tradução de Karina Jannini, São Paulo: Martins Fontes, 2004.

HARRIS, John. Stem Cells, Sex and Procreation In: KUHSE, Helga; SINGER, Peter (Ed.). Bioethics - An Anthology. 2 ed. Oxford: Blackwell, 2006.

JONAS, Hans (1979). O Princípio Responsabilidade - Ensaio de uma Ética para a Civilização Tecnológica. Tradução de Marijane Lisboa e Luiz Barros Montez. Rio de Janeiro: Contraponto; PUC-Rio, 2006.

MANNINEN, Bertha Alvarez. Respecting Human Embryos Within Stem Cell Research: seeking harmony. Metaphilosophy, New Haven, v. 38, n. 2-3, p. 226-244, Abr. 2007.

MARQUIS, Don. The Moral-Principle Objection to Human Embryonic Stem Cell Research. Metaphilosophy, New Haven, v. 38, n. 2-3, p. 190206. Abr. 2007.

MAURON, Alexandre. Embryo and Fetus - Development from Fertilization to Birth In: POST, Stephen G. (Ed.). Encyclopedia of Bioethics. 3 ed. v. 2. Nova York: Macmillan, 2007. p. 707-712.

MCMAHAN, Jeff. Killing Embryos for Stem Cell Research. Metaphilosophy, New Haven, v. 38, n. 2-3, p. 170-189, Abr. 2007.

. The Ethics of Killing: Problems at the Margins of Life. New York: Oxford University Press, 2002.

ODERBERG, David S. (2008) The Metaphysical Status of the Embryo: Some Arguments Revisited. Journal of Applied Philosophy, Hull, v. 25, n. 4, p. 263-276, Nov. 2008.

ORD, Toby. The Scourge: Moral Implications of Natural Embryo Loss. The American Journal of Bioethics, Kansas City, v. 8, n.7, p. 12-9, Jul. 2008. 
PARFIT, Derek. Rights, Interests and Possible People In: KUHSE, Helga; SINGER, Peter (Ed.). Bioethics - An Anthology. 2 ed. Oxford: Blackwell, 2006. 202-221, Dez. 1997.

. Equality and Priority. Ratio new series, Malden, v. 10, n. 3, p. . Reasons and Persons. New York: Oxford University Press, 1984. PERSSON, Ingmar; SAVULESCU, Julian. Actualizable Potential, Reproduction and Embryo research: Bringing Embryos into Existence for Different Purposes, or Not at All. Cambridge Quarterly of Healthcare Ethics, Cambridge, v. 19, n. 1, p. 61-74, Dez. 2010.

. Actualizable Potential, Reproduction and Embryo research: Bringing Embryos into Existence for Different Purposes, or Not at All. Cambrige Quaterly of Healthcare Ethics, Cambridge, v. 19, n.1, p. 61-74, Dez. 2010.

RAWLS, John. A Theory of Justice. Cambridge: Harvard University Press, 1971.

RESNIK, David; VORHAUS, Daniel. Genetic modification and genetic determinism. Philosophy, Ethics, and Humanities in Medicine, Londres, v. 1, n. 9, p. 01-09, Jun. 2006.

SAGAN, Agata; SINGER, Peter. The Moral Status of Stem Cells. Metaphilosophy, New Haven, v. 38, n. 2-3, p. 264-284, Abr. 2007

SANDEL, Michael. The Case Against Perfection - ethics in the age of genetic engineering. Cambridge / Londres: Harvard University Press, 2007.

SAVULESCU, Julian; KAHANE, Guy. The moral obligation to create children with the best chance of the best life. Bioethics, Malden, v. 23, n. 5, p. 274-290, Jun. 2009.

. Procreative Beneficence: Why we Should Select the best children? Bioethics, Malden, v. 5/6, n. 15, p. 143-426, Out. 2001.

. The Embryonic Stem Cell Lottery and the Cannibalization of Human Beings, Bioethics, Malden, v. 16, n. 6, p. 508-529, Nov. 2002.

. Sex Selection: The Case For. In: KUHSE, Helga; SINGER, Peter 
(Ed.). Bioethics - An Anthology. 2 ed. Oxford: Blackwell, 2006.

. Genetic Interventions and the Ethics of Enhancement of Human Beings In: STEINBOCK, Bonnie (Ed.). (2007). The Oxford Handbook of Bioethics. Oxford: OUP, 2007.

SINGER, Peter. Practical Ethics. New York: Cambridge University Press ${ }^{2}$, 1993.

STEINBOCK, Bonnie. Preimplantation genetic diagnosis and embryo selection In: BURLEY, Justine; HARRIS, Johh (Ed.). A Companion to Genethics. Oxford: Blackwell, 2002. . Moral Status, Moral Value, and Human Embryos: Implications for Stem Cell Research In: . (Ed.). The Oxford Handbook of Bioethics. Oxford: OUP, 2007.

WARREN, Mary Ann. Moral status: obligations to persons and other living things. Oxford: Oxford University Press, 2000.

Data de registro: $25 / 10 / 2010$

Data de aceite: 16/02/2011 
